\title{
The Dimensions of a Conflict: the Case of Macedonia.
}

\author{
Aida Goga \\ Phd Candidate, Albanian Institute of European Studies \\ Email: aida_goga@yahoo.com
}

\section{Doi:10.5901/mjss.2013.v4n10p16}

\begin{abstract}
The region of Balkan is still considered as fragile with nations that have not finished the state-formation and with conflicts that are still alive and actual. The central problematic of the Balkan of the last twenty years was the former republic of Yugoslavia, after the dissolution of which these conflicts were fomented even more, while Bosnia at the beginning of the nineties witnessed the hardest war of all the other Yugoslavian countries, Macedonia escaped from this war and witnessed only a short-period interethnic conflict in 2001. The armed conflict between the Macedonian and Albanian forces reinforced the relationship and cooperation with EU and put an end to the Ohrid Framework Agreement in 2001. Macedonia still functions as a mono-ethnic state, even though the spirit of the Ohrid Framework Agreement was the construction of the civilian state and the two main principles were to respect the cultural identity and the equal rights of all citizens. In this context, the aim of this study is to analyze the dimension of the ethnic conflicts in Macedonia during two periods, before year 2001 and after this year, based on the three theoretical perspectives: the conflict management theory, the conflict resolution theory and the conflict transformation theory. According to many researchers of this issue the Ohrid Framework Agreement was an compromise to resolve the conflict where international actors were attempting to resolve the tensions between the Albanian and Macedonian ethnic communities and according to some other researchers the Ohrid Framework Agreement put an end to the conflict, but it did not put an end to the sources of this conflict.
\end{abstract}

Keywords: ethnic conflict, Ohrid Framework Agreement, conflict resolution, conflict theories

\section{Introduction}

The Republic of Macedonia is one of the countries born out of the dissolution of Yugoslavia, a process that caused interethnic and inter-religious conflicts, social traumas and a very pessimistic picture for the future of the Balkan and its inhabitants. The crisis was very complex and was characterized by a tension curb of progressive conflicts, starting with the detachment of Slovenia, Croatia and Macedonia in 1991, going on with the climax of the crisis of Bosnia-Herzegovina in 1994-1995, and reaching its climax in 1998-1999 with the crisis of Kosovo and at last with the interethnic conflict of 2001 in Macedonia, between the national army and the Albanian guerrillas, that saw the end with the Framework Agreement signed in Ohrid on August 13 of the same year. The aim of this agreement was to put the Albanian community on the same level of the rest of the citizens, by recognizing their language as co-official in the municipalities with more than $20 \%$ of Albanian population and guaranteeing a major presence in the institutions.

"Generally speaking, the grants given by the Ohrid Agreement have not created a condition of full equality between Albanians and Macedonians. The Ohrid Framework Agreement put an end to the conflict, but it did not put an end to the sources of this conflict."(Reka, B 2007)

Many researchers have made different analyses based on different perspectives and we can say that in all the studies of the conflict there exists a vacuum and still does not exist an all-embracing theory which explains all the causes of the conflict. The methodology of the analyses is based on the historical aspect of the conflict, the main problem and the participative parties in an international and regional level, and also on the experiences gained from the previous conflicts. Balkan's postwar societies, and especially the Macedonia case, render the picture of being powerless in the constructive approach towards conflicts, embracing the approach of entering the conflicts spiral, which for one moment was interrupted only by the influence of external forces whereas the conflict is still active and burning itself and still results, but in another level, being further sustained by powerful structures.

The conflicts in Macedonia have taken different shapes and frames during the different historical, social and political phases. "When talking about interethnic relationships in Macedonia, it is about a pretty sensitive and flexible problem which entwists itself in all the pores of life beginning from the family and ending with the governmental institutions. This problem's actuality is and will always be present up to the moment these problems will be properly 
worked out." (Maliqi 2001, 26)"So, what we see, nowadays, Macedonia is a country composed of two virtual parallel societies for ethnic Macedonians and ethnic Albanians, that have neither a way, nor intention to communicate and interact with each other, with the end result of a vicious circle misunderstandings prejudices and an ever high tension."

The last incidents in Macedonia memorialized the fact that the interethnic tensions, unfortunately, don't belong only to the past. But, a decade after its signing, the Ohrid Framework Agreement has not yet been fully implemented, and the tensions between the two major ethnic groups are still very much present. Consequently naturally the question arises: can conflicts be prevented, resolved, managed or transformed into new shapes and structures?

\section{The conflict theories}

Since the conflicts mark a turning point in the social life, with great consequences and implications in people's lives, their knowledge and treatment still remain a priority task to the states that aspire a democratic society."The most difficult conflict types are those in which abstract elements are included, such as ethnic hatred, religious zeal or ideology. The connotation of ethnic conflicts is not based on tangible issues concerning what someone does but it is based on abstract issues concerning what someone is."(Goldeshtein 2001, p 214).

Ethnically diverse societies carry various degrees of conflict potential. Ethnic emotions, rooted in historical memories of grievances, are at the core of conflict potential. Ethnicity, as Horowitz argues, "embodies an element of emotional intensity that can be readily aroused when the group's interests are thought to be at stake."(Horowitz 1985, p 59).

All multi-ethnic societies, when subject to a convergence of a particular set of factors and conditions, carry the potential of ethnic conflict. Under the stress of a major structural change that brings a sense of chaos and uncertainty, the consciousness of historically rooted ethnic identities and emotions are employed as vehicles to ethnic violence for political purposes. Viewing historically rooted ethnic animosities as the only cause of conflict is insufficient. As Ganguly argues, "A proper understanding of the causes of ethnic political mobilization and conflict is crucial, and we must move beyond simplistic discussions of 'ancient hatreds' to search for more systematic explanations."(Ganguly 1995, p 49).

"The context of conflict includes the society in conflict and the wider international and regional level. Within the society, crucial background aspects are culture, governance arrangements, institutions, social roles, norms, the rules and codes in place in a society, and its path of development. For example, in conflicts involving ethnicity, minorities or challenges to state structures, it is the very structure of the state that is at issue."(Miall 2004, p 8). A special discussion over conflicts is given by three separate schools witch approaches different conceptualizations of conflict. (Miall 2004, $p$ 15)

In Miall's analysis Conflict transformation theorists argue that contemporary conflicts require more than the reframing of positions and the identification of win-win outcomes. The very structure of parties and relationships may be embedded in a pattern of conflictual relationships that extend beyond the particular site of conflict. Conflict transformation is therefore a process of engaging with and transforming the relationships, interests, discourses and, if necessary, the very constitution of society that supports the continuation of violent conflict. Constructive conflict is seen as a vital agent or catalyst for change. People within the conflict parties, within the society or region affected, and outsiders with relevant human and material resources all have complementary roles to play in the long-term process of peace-building. This suggests a comprehensive and wide-ranging approach, emphasizing support for groups within the society in conflict rather than for the mediation of outsiders. It also recognizes that conflicts are transformed gradually, through a series of smaller or larger changes as well as specific steps by means of which a variety of actors may play important roles.

In Miall's analysis conflict management theorists see violent conflicts as an ineradicable consequence of differences of values and interests within and between communities. The propensity to violence arises from existing institutions and historical relationships, as well as from the established distribution of power. Resolving such conflicts is viewed as unrealistic: the best that can be done is to manage and contain them, and occasionally to reach a historic compromise in which violence may be laid aside and normal politics resumed. Conflict management is the art of appropriate intervention to achieve political settlements, particularly by those powerful actors having the power and resources to bring pressure on the conflicting parties in order to induce them to settle. It is also the art of designing appropriate institutions to guide the inevitable conflict into appropriate channels.

In Miall's analysis Conflict resolution theorists, in contrast, reject this power political view of conflict, arguing instead that in communal and identity conflicts, people cannot compromise on their fundamental needs. However, they

${ }^{1}$ http://www.macedonia.org/crisis/story1.html2001/2, p.152.Retrieved on April 26,2013 
argue that it is possible to transcend conflicts if parties can be helped to explore, analyze, question and reframe their positions and interests. Conflict resolution therefore emphasizes intervention by skilled but powerless third-parties working unofficially with the parties to foster new thinking and new relationships. They seek to explore what the roots of the conflict really are and to identify creative solutions that the parties may have missed in their commitment to entrenched positions. Conflict resolution is about how parties can move from zero sum, destructive patterns of conflict to positive-sum constructive outcomes. The aim is to develop processes of conflict resolution that appear to be acceptable to parties in dispute, and effective in resolving conflict.

Many researchers have made different analyses based on different perspectives and we can say that in all the studies of the conflict there exists a vacuum and still does not exist an all-embracing theory which explains all the causes of the conflict.

\section{Analysis of ethnic conflicts in Macedonia before the Ohrid Framework Agreement}

The Republic of Macedonia is one of the countries born out of the dissolution of Yugoslavia, a process that caused interethnic and inter-religious conflicts, societal traumas and a very pessimistic picture for the future of the Balkans and its inhabitants. It cannot be said that interethnic conflicts between the Albanians and the Macedonians have started in 2001, which means that this problematic has its historical dimension. In retrospective, ethnic conflicts in Macedonia generated in 1913. The Conference of London, which ended the 1912-1913 Balkan War, gave birth to the Albanian State, whereas Macedonia became part of Serbia." Macedonia included a portion of territory, the western regions, populated by Albanians, which, following the logic we saw above should have been given to Albania. After the Second World War, the Macedonian population had highly grown, especially the Albanians. Between 1953 and 2001, the Albanians had grown by $31.3 \%$, from $12.4 \%$ to $25 \%$ of the population." (Lebamof, llevski 2008, p8).

Macedonia's recent history can be divided into two main periods: the communist era 1945-1990 and the independent society 1991 to now. The second period, that of independence, also can be treated as two phases: before the conflict 2001 - or before Ohrid Agreement and after 2001. The Ohrid Agreement is especially important because it changed the character of the state from a mono-ethnic to multi-ethnic society and institutionalized the multicultural character of Macedonian society, effectively turning Macedonia into a multicultural state. Macedonia is an emphatically multiethnic country, which implies the fact that it is a multilingual setting where different ethnicities live: Macedonians, Albanians, Serbs, Vlachs, Roma, Bulgarians, and in which different languages are spoken: Macedonian, Albanian, Turkish, Serbian, Vlach, Bulgarian, and Romani.

The continual conflicts in Macedonia have been ethnic conflicts between Macedonians and Albanians. One of the sources of the deteriorated interethnic relationships between the Albanians and the Macedonians was an offspring of the failure to resolve the judicial constitutional status of the Albanians in Macedonia, where in the preamble of the Constitution of the Republic of Macedonia states that:"Macedonia is established as a national state of the Macedonian people, in which full equality and permanent co-existence with the Macedonian people is provided to Albanian, Turks, Vlachs, Roma and other nationalities living in the Republic of Macedonia". ${ }^{2}$ Starting from this fact, for a long period of time Macedonia suffered a political crisis with significant interethnic elements and considering it as a generator of this crisis, even for the conflict of 2001 it was the unitary character of the state which favors a nation, a language and a religion, the Orthodox, sanctioned in the Constitution of 1991, which presented a continual risk to the future of Macedonia as a state. (Fejziu 2012, p, 78)

Earlier, "the constitution of the Socialist Federal Republic, adopted in 1945, recognized the right of the Albanian community to be culturally autonomous and use their language, and the Communist Party had tried to integrate the Albanians with educational trainings and professional opportunities. This policy started to change in 1989, when, like in Kosovo, even in Macedonia the Albanians were no longer allowed to express their culture. The writings in their language were removed from the billboards, and the Albanian given names were forbidden. The prohibition for the Albanians to have more than two children was also introduced."3

Analyzing the sources of the interethnic conflicts between the Albanians and the Macedonians according to a chronology, from 1974, this was a year of hope for the Albanians of Macedonia, who with the constitution of year 1974 gained an equal status to the Macedonians and were a consecutive element of the state. Unfortunately, the rights of the Albanians in Macedonia remained only in a theoretical character, and never did these rights appear to be operational. Year 1981 was also a year full of negative repercussions to the Albanians of Macedonia where begins an unprecedented

\footnotetext{
2 Constitution of the Republic of Macedonia, Preamble, 1991. Retrieved on April 19,2013

3 http://travel2macedonia.com.mk/event/indepence-of-macedonia. Retrieved on May 062013
} 
repression towards them and especially towards the intelligence, which reaches its climax in 1989, a year which is considered in the south-eastern Europe as the period of political and economical changes, namely the revolution of this part of Europe. The totalitarian character of the previous system was unable to resolve the national Albanian issue. The failure to respect the fundamental rights and freedoms, the domination and the superior position of the majority ethnic group, and also the inferior position of the minority ethnic group with special emphasis the position of the Albanians, and the systematical repression towards them, all this resulted in the collapse of that system.

"After the collapse of the totalitarian systems again the issue was open: would the people that had lived in these famous communions have the right of self determination? This right was allowed to all the people of the ex-Yugoslavian space whereas to the Albanians it was denied. The events that took place in ex-Yugoslavia, with all their turbulences were reflected in Macedonia too, and especially the interethnic tensions and frictions between the Albanians and the Macedonians should be taken into account, as two major ethnic groups" (Maliqi 2001, p 54). The implementation of the Framework Agreement- signed in Ohrid in August 13, 2002 still remains the measuring tool of the progress in Macedonia from the mutual conflict to the democratic stability. "But, ten years after its signing, the Ohrid Framework Agreement has not yet been fully implemented, and the tensions between the two major ethnic groups are still very much present” (Reka,B 2007.)

\section{Why did the conflict in Macedonia arise after the Ohrid Framework Agreement?}

The war in Macedonia was the only case from the wars in the former Yugoslavia which did not occur for territories, but for the status of state-building and equal rights to all its citizens.

"The Agreement guarantees the introduction of participative mechanisms when making decisions related to the communities' identity; equitable representation of the members of non-majority communities in the public administration; a high level of decentralization; promotion of the official use of non-majority languages and alphabet, as well as the communities' symbols; and higher education in the language of the non-majority communities that represent at least 20\% of the population. As a result the implementation of the Ohrid Framework Agreement represents one of the guarantees for the multicultural and inter-ethnic co-existence on Macedonia and is on the main priorities for the EU integration and for the Macedonian government according to the Framework Agreement Plan adopted in 2003."

While analyzing the dimensions of different conflicts Miall analyze the conflict in Macedonia in 2001, interpreting it as a Cooperative Multi-Track Diplomacy relying on the theorists of conflict transformation: Macedonia offers a case in which the various initiatives of different tracks appear to have been genuinely complementary. For example, the OSCE High Commissioner on National Minorities (external Track I) together with the Open Society Institute in Skopje (internal Track III) proposed several compromise solutions on the university issue.(Miall 2001,15) "Is the Ohrid Framework Agreement a political agreement (signed by legitimate political leaders of the ethnic Macedonian and ethnic Albanian political parties) or a peace agreement (signed under the mediation of EU and US representatives, ending the violent confrontation of security forces and National Liberation Army"? (Ackermann 2001, pp117-135). If on an Albanian interpretation, the OFA was a settlement of a long-running mostly non-violent conflict based on state exclusion of the Albanian population, on a Macedonian interpretation it is primarily a peace agreement, whereby Macedonian state is pressured by the international community to concede considerable political ground (Hislope 2003).

In an analysis the Albanian researcher Reka.B (2011) stresses two periods which do not treat the problem in the same context. The first period: 2002-2006, we might say, was a satisfactory period for the Implementation of the Ohrid Framework Agreement. During the first four years, the Ohrid Agreement was mainly implemented but it did not meet the imposed implementation deadline of 2004. The second period: 2006-2010, noted serious shortcomings in the implementation of the Ohrid Framework Agreement, and it set aside the inter-ethnic relations. The main focus during these four years was mainly concentrated on the so-called "name dispute", hence neglecting the conflict for the state. The issue of the name was imposed before the state, although the conflict in 2001 did not begin due to the name but because of the discriminatory position of the Albanians in Macedonia. With such a shift of political priorities - after four years, under the pressure of the so-called "resolving name dispute with Greece", the implementation of the Ohrid Framework Agreement was left aside even in this second period. The Ohrid Framework Agreement put an end to the conflict, but it did not put an end to the sources of this conflict. (Reka.B 2011,14).

Furthermore ten years after the Ohrid Framework Agreement the results of the Center for Inter-ethnic Tolerance say that the inter-ethnic relations in Macedonia are approaching a conflict. According to this centre, above $70 \%$ of the

${ }^{4}$ National Strategy for European Integration of the Republic of Macedonia, 2004. Retrieved on April 27,2013 
citizens say that the inter-ethnic tensions have increased, whereas only $20 \%$ of them say that they are at a good level. According to the leaders of this Centre, similar results have been met also in the conflict in 2001. The questionnaire shows that the Albanians are upset that a mosque is not built in the centre of Skopje; the Macedonian pupils refuse to learn Albanian and the Roma have repeated that they feel themselves to be second-rate citizens. ${ }^{5}$

According to a study of UNDP for the Interethnic Tensions in Macedonia results that the inter-ethnic tensions are still present and the main threats to the good inter-ethnic relations are still existing and effective. The level of estimated danger for an ethnic-based conflict in the country is rather low, but it varies from one ethnicity to the other. Ethnic Macedonians believe that the risk is greater, probably because they still experience the interethnic relations as rather poor and look upon the ethnic Albanians as potential source of violence. Ethnic Albanians do not see danger, probably because they perceive the interethnic relations mainly as good and believe that the reasons for a violent conflict have already been removed. There are more optimists among the ethnic Albanians when it comes to improvement of the interethnic relations, than among the ethnic Macedonians. ${ }^{6}$

The US State Department Human Rights Report for year 2009 states that during the last year the support that the state gave to the construction of the Orthodox church in the centre of the capital has tensioned the interethnic relations, and has generated issues related to the separation of the Church from the State ( Human Rights Report: Macedonia, 2009).

Another fact that serves as a reason why the ethnic Albanian-Macedonian relations are so tensioned is related to the fact that one of the Macedonian culture centrism "products" was the publishing of the "Macedonian Encyclopedia", prepared Macedonian Academy Of Arts and Sciences and financed by the government. This two-volume book offends the Albanians by calling them, mountain people (mountaineers) etc., and describing them as vandals who have upset the Macedonians; thus it is a text which highly deteriorated inter-ethnic relations. ${ }^{7}$

The senior commissioner of the OSCE for the minorities, Knut Volebek, said that: "The flag burning, expressing hatred language, and also the violence shown towards the religious monuments, talk about a politics, which, if not prevented, can present a serious problem about the democratic developments in the country". The last incidents are indicators that there are tensions and that little are needed for the situation to be aggravated and to get out of control. The last incidents in Struga commemorated that interethnic tensions, unfortunately, do not belong to the past. If they are not greatly hindered, they represent a threat to the society in general in Macedonia. ${ }^{8}$

\section{Conclusions}

Since the conflicts mark a turning point in the social life, with great consequences and implications in peoples' lives, their knowledge and treatment still remain a priority task to the states that aspire a democratic society. "Ethnic conflict is a case by case story and a complex phenomenon."(Crocker 1995). There is no single cookie-cutter approach that will work, Crocker argues that "the important point is that those who decide to intervene have an obligation to develop their own definition of success, and to keep it firmly in mind while laboring to avoid becoming part of the problem and making things worse."(Crocker 1995) The Ohrid Framework Agreement was a document that emerged from the conflict of 2001 and was based mainly in the compromise between parties and objectively it could not offer a definitive solution for the juridical constitutional position of the Albanians, from the minority position to that of the equal nation with the Macedonians. These two entities should go towards the finding of a consensus to cohabit. To build good interethnic relationships, the Macedonian politics and the State Leadership should change the approach towards the Albanian ethnicity. Considering these theoretical basis is noticed that nowadays Macedonia needs a reformation, for an education with cosmopolitan concepts, because it is still charged with ego-centric, ethno-nationalist concepts, that have remained from its past. This change can be made by the European Union working with the institutions of the state of Macedonia, by guiding them toward the multiculturalism, the cosmopolitanism, the modernism etc. The building of these relationships between the Albanian and Macedonian ethnicity, has to be organized with the support of all the social categories, from the political, intellectual elite, the EU, the local and international nongovernmental organizations. "The different ethnic identities are not artificially created; therefore they should not be ignored. The language, the writing, the religion, the symbols are very

\footnotetext{
${ }^{5} \mathrm{Http}: / /$ lajme.parajsa.com/Rajoni/id_150417/03, February, 2010. Retrieved on May 11,2013

${ }_{6}^{6}$ People Centred Analyses Report; Ethnic Dimensions of Social Inclusion, UNDP,2008. Retrieved on May 09, 2013

7 Enciklopedia, Reagime, Koha, Shkup, 2009, p. 310, 322 . Retrieved on April 20, 2013

8 Newspaper."Bota Sot" 09 Feb, 2012, Shkup, Macedonia .Retrieved on May 082013
} 
important to people because they talk about their identity. For a long time, the usage of the Albanian language in the institutions, the right to education in mother tongue, the usage of the national flag was denied to the Albanians; even violence was used to prohibit them from exercising these vital rights." (Maleska, Hristova, 2006, p, 100) What can be said is that there is no time for the arising of ethnic conflicts neither in Macedonia nor in Balkan, given that Balkan was in conflict for centuries.

\section{References}

Ackermann, A. (2001) On the Razor's Edge: "Is There Still a Place and Time for Long-term Conflict Prevention in Macedonia?" Paper presented at the Annual International Conference of the Centre for South East European Studies (CSEES), University of London, June 14-16

Council of the European Union, EU Annual Reports on Human Rights, European Communities, Brussels, 2005, p,18

Crocker, Ch. (1995)"Lessons on Intervention," in Managing Conflict in the Post-Cold War World: The Role of Intervention. Report of the Aspen Institute Conference, August 2-6, pp.77-88

European Platform for Conflict Prevention (1999a,b.) Retrieved on May 04, 2013

Fejziu, M. (2012)"Federalizimi i maqedonise eshte Conditio sine qua non", Revista Diskutime 2012, p,78

Godeshtein, J. (2001)"International Relations",American University, Washington D.C p,214.

Hislope, R. (2003) "Between a Bad Peace and a Good War: Insights and Lessons from the Almost-War in Macedonia", Ethnic and Racial Studies 26, no. 1 129-151.

Horowitz, D. (1985)" Ethnic Groups in Conflict, Los Angeles": University of California Press, 19 p. 59

http://www.macedonia.org/crisis/story1.html2001/2,p.152. Retrieved on May 06, 2013

http://www.wilsoncenter.org/publication/134-preventing-ethnic-conflict-macedonia-and-the-pluralist-paradigm Steven I.Burg. Retrieved on May, 022013

Lebamof,M \& Ilevski,Z.(2008)The Ohrid Framework Agreements: Neither Settlements nor Resolution of Ethnic Conflict, International Studies Association Conference, San Francisco, September 26-29 2008, p,8.

Macedonia, Human Rights Review, Vol. 9, No. 1, pp. 55-69

Maleska,M \& Hristova,L(2006) "Spodeluvanje na vlasta vo multikulturnite opstini vo Republika Makedonija", Godisnik na institutot za socioloski i politiko-pravni istrazuvanja, Univerzitet "Sv. Kiril I Metodij" Shkup, nr. 1, f. 100

Maliqi, N.(2001)"Toleranca politike në funksion të paqes", Fondacioni Friedrich Ebert,Shkup, Ganguly, R.(1995)"Why Do Ethnic Groups Mobilize?" (Chapter 3) in R. Taras, ed., National Identities and Ethnic Minorities in Eastern Europe, Selected papers from the Fifth World Congress of Central and East European Studies, Warshaw. p. 49

Reka, B. (2011),"A New Political Philosophy for the Functioning of a Multi-ethnic State" Conference: Ten years from the Ohrid Framework Agreement.UEJL,Macedonia 